\title{
Artificial Heme Enzymes for the Construction of Gold-Based Biomaterials
}

\author{
Gerardo Zambrano 1®D, Emmanuel Ruggiero ${ }^{1,+}{ }^{\dagger}$ Anna Malafronte ${ }^{1}$, Marco Chino 1®D, \\ Ornella Maglio ${ }^{1,2}\left(\right.$, Vincenzo Pavone ${ }^{1}$, Flavia Nastri ${ }^{1, *}$ and Angela Lombardi ${ }^{1, *}(\mathbb{D}$ \\ 1 Department of Chemical Sciences, University of Napoli “Federico II” Via Cintia, 80126 Napoli, Italy; \\ gerardo.zambrano@unina.it (G.Z.); emmanuel.ruggiero@basf.com (E.R.); anna.malafronte@unina.it (A.M.); \\ marco.chino@unina.it (M.C.); ornella.maglio@unina.it (O.M.); vincenzo.pavone@unina.it (V.P.) \\ 2 Istituto di Biostrutture e Bioimmagini, CNR, Via Mezzocannone 16, 80134 Napoli, Italy \\ * Correspondence: flavia.nastri@unina.it (F.N.); alombard@unina.it (A.L.); Tel.: +39-081-674419 (F.N.); \\ +39-081-674418 (A.L.) \\ † Current address: BASF SE, Dept. Material Physics, Carl-Bosch-Strasse 38, 67056 Ludwigshafen, Germany.
}

Received: 30 July 2018; Accepted: 19 September 2018; Published: 24 September 2018

\begin{abstract}
Many efforts are continuously devoted to the construction of hybrid biomaterials for specific applications, by immobilizing enzymes on different types of surfaces and/or nanomaterials. In addition, advances in computational, molecular and structural biology have led to a variety of strategies for designing and engineering artificial enzymes with defined catalytic properties. Here, we report the conjugation of an artificial heme enzyme (MIMO) with lipoic acid (LA) as a building block for the development of gold-based biomaterials. We show that the artificial MIMO@LA can be successfully conjugated to gold nanoparticles or immobilized onto gold electrode surfaces, displaying quasi-reversible redox properties and peroxidase activity. The results of this work open interesting perspectives toward the development of new totally-synthetic catalytic biomaterials for application in biotechnology and biomedicine, expanding the range of the biomolecular component aside from traditional native enzymes.
\end{abstract}

Keywords: gold nanoparticles; artificial enzymes; immobilization strategies; catalytic activity; peroxidases; functional biomaterials

\section{Introduction}

Extensive progress in protein design and engineering enables the construction of artificial metalloenzymes showing efficiency and substrate diversity beyond those of natural systems [1-12]. Heme-containing enzymes active in oxidation chemistry are a fascinating source of inspiration for researchers [13]. Indeed, recent outstanding results demonstrated that artificial biocatalysts with new reactivity can be successfully developed, by redesigning, modifying and/or mimicking heme-enzymes. Redesign of heme-proteins, through engineering and/or reconstitution with different porphyrin-like cofactors, allows shaping new functions into native proteins [14-18]. By mimicking Nature's strategy, directed evolution successfully allows repurposing enzymes, such as Cytochrome P450, thus developing catalysts for reactions not familiar to the biological systems [19-23]. Further, rational design and de novo design approaches have allowed the construction of artificial peroxidases with enzymatic rate constants outperforming those of their natural counterparts [24,25].

The potential of artificial metalloenzymes will be fully exploited once the results from basic science are transferred into specific technological applications, such as in biotechnology and industrial catalysis. Merging the advantages of designed enzymes and immobilization strategies could be an important step toward these goals [26]. In this view, the tools available today for the chemical modification of enzymes 
have strongly increased the variety of functional biomaterials that can be developed. Nowadays, enzymes are widely used in several biotechnological and biomedical applications, thanks to a variety of strategies implemented for their conjugation and/or immobilization onto different matrices [27]. Conjugation of enzymes to solid supports and/or nanomaterials has been used for the development of bio-devices with a variety of functions, ranging from biosensing, to drug delivery, targeting and imaging [28-30]. The utility and effectiveness of these bio-conjugates relies on the combination of the unique properties of the solid supports and/or nanomaterials with those of the biomolecular components [31-34].

In particular, gold-based materials are well suited for the immobilization of redox-active enzymes [31]. They allow electron exchanges with the biomolecular components thus being of great interest in the field of electrochemical biosensors. Further, gold nanoparticles (AuNPs) have emerged as useful nanomaterials for enzyme immobilization because of their surface chemistry and unique electronic, magnetic and optical properties [35]. In addition, immobilization of enzymes on AuNPs represents a middle ground between heterogeneous (immobilized enzymes) and homogeneous (soluble free enzymes) catalysis [36].

Heme-proteins have been successfully immobilized onto different supports for diverse applications $[37,38]$. They can rapidly exchange electrons with electrodes, by a direct reversible electron transfer, and Cytochrome $c$ is one of the most studied heme-protein in this respect [37]. Further, the immobilization of electro-active enzymes, such as Cytochrome P450, on gold electrodes is a useful strategy for the development of biosensors and screening platforms for drug development [38,39]. Peroxidases and catalases have often been conjugated to AuNPs and to other super-paramagnetic nanoparticles, and the applications of these bio-nano-conjugates have been successfully exploited in immunoassays or biosensor development [33,40]. For example, horseradish peroxidase (HRP) entrapped onto layers of gold nanoparticle-thionine-chitosan absorbed on a glassy carbon electrode (GCE) was applied as signal amplification system, for the electrochemical biosensing of tetrahydrocannabinol [41]. Similarly, by encapsulation on nanogold hollow spheres, HRP was used for signal amplification in the electrochemical detection of hepatitis $C$ virus [42].

Substituting natural enzymes with properly designed metalloenzymes would be valuable for the development of new hybrid and functional biomaterials. First, it would expand the set of available biomolecular components beyond the natural system. Further, fine-tuning the enzyme performances by design should open the way to the construction of nanoparticles/artificial enzyme conjugates tailored for specific applications.

In this view, we exploited the applications of mimochromes, artificial peroxidases developed by us through a miniaturization approach $[1,13,24,43-54]$, for the construction of totally synthetic functional bioconjugates. Their simple structure (Figures 1 and S1), made up by two helical peptide chains sandwiching an iron-porphyrin, allowed shaping a proximal and distal face around the metal cofactor, thus resembling natural heme-proteins [24,50,52]. Starting from the prototype Mimochrome I [43-45], in which the presence of two histidine (His) residues in each peptide chains afforded a symmetric bis-His hexa-coordinated complex, several rounds of redesign allowed the development of catalytically active derivatives $[24,50,54]$. In particular, replacement of the axial-coordinating His in one chain, with a smaller residue unable to coordinate the metal ion, provided five-coordinated complexes with an empty site available for substrate binding and transformation $[24,50,54]$. Several analogs of the mimochrome family have been fully characterized, displaying both reversible $\mathrm{Fe}(\mathrm{III}) / \mathrm{Fe}(\mathrm{II})$ redox behaviors and peroxidase catalytic activity $[48,50,52,54]$. The properties of Fe(III)-Mimochrome VI (the first developed five-coordinated complex), herein referred to as MC6 [50,52], have already been investigated upon immobilization on electrode surface, by exploiting physical adsorption on either gold electrode coated with decane-1-thiol or on mesoporous conductive films of tin-doped indium oxide (ITO) [52,53].

In this work, a derivative of the mimochrome family, specifically Fe(III)-S6G(D)-MC6 (named as MIMO throughout the text), was immobilized on gold-based materials. A crucial issue in the 
immobilization of enzymes onto different supports is to find the optimal conditions to preserve catalyst functionality [55-57]. The covalent attachment of heme-enzymes, through thiol-based self-assembled monolayers (SAMs) on gold, is one of the most applied methods for ensuring enzyme direct electrical contact with electrodes $[37,58,59]$. For AuNPs, numerous studies have been devoted in finding the optimal solution for interfacing catalytic and redox active enzymes on nanoparticles. In particular, the use of AuNPs in aqueous solutions requires their stabilization in a finely dispersed state [60]. For this purpose, the use of a proper coating moiety is mandatory. Based on these considerations, MIMO was functionalized with lipoic acid (LA) to construct a building block that can easily be grafted onto different gold-based supports, such as gold electrodes or AuNPs (see Figure 1).

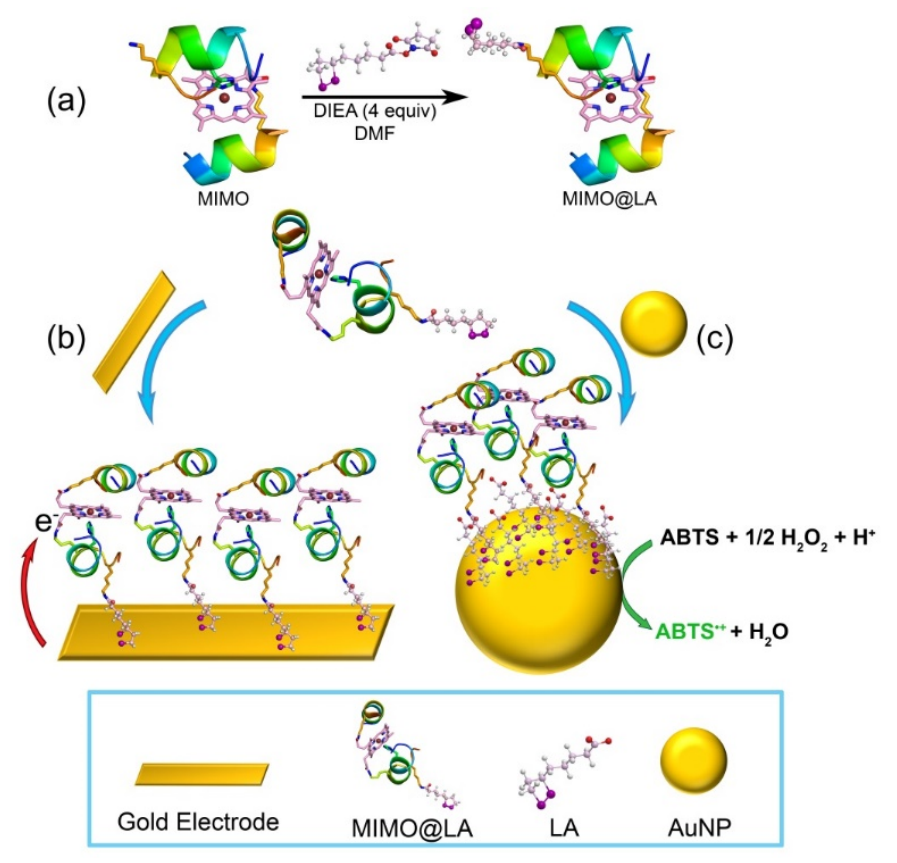

Figure 1. MIMO lipoamide (MIMO@LA): A versatile building block for the construction of synthetic gold-based biomaterials. (a) Strategy for MIMO@LA synthesis (DIEA: diisopropylethylamine; DMF: $\mathrm{N}, \mathrm{N}$-dimethylformamide; experimental conditions are reported in Section 3.1). (b) Immobilization of MIMO@LA on gold electrode affords a redox active interface. (c) Conjugation to gold nanoparticles (AuNPs) gives a catalytic system for substrate oxidation. The oxidation of the chromogenic substrate 2,2' -azino-bis (3-ethylbenzothiazoline-6-sulphonic acid) (ABTS) to ABTS radical cation (ABTS ${ }^{\bullet}$ ) is reported as an example.

Herein, we demonstrate that the artificial catalyst displays quasi-reversible redox properties and peroxidase activity, even upon immobilization. Collectively, the straightforward synthesis of MIMO@LA and the simplicity of the immobilization strategy on gold-based supports offer wide perspectives in biosensing and catalysis.

\section{Results and Discussion}

\subsection{Synthesis of MIMO@LA}

In this work, we explored the feasibility of using LA-modified MIMO for its direct immobilization on gold-containing materials. Amino groups of proteins can be converted into thiols by the use of bi-functional linkers, containing both a thiol and a carboxylic group. Among sulfur-containing bi-functional linkers, LA has been widely applied for the preparation of a variety of stable conjugates, useful for different applications [61-66].

MIMO (see Figure S1 for details) was synthesized following a previously developed procedure [50,54]. It was purified to homogeneity by reverse phase—-high performance liquid chromatography (RP-HPLC), 
and electrospray ionization-mass spectrometry (ESI-MS) confirmed the expected molecular weight (3521.2 amu). For a more detailed description of synthetic protocols and results, please refer to Supplementary Materials (Section S2.1 and Figure S2). The UV/Vis spectrum at neutral pH (Figure S3) is representative of a high spin ferric porphyrin, with $\mathrm{His}-\mathrm{H}_{2} \mathrm{O}$ axial coordination [50]. Conjugation of MIMO to LA was accomplished through several simple steps (see Scheme S1). The presence of a single Lys residue, in one of the two peptide chains, exposed to the solvent, suggested the use of its side chain as reactive group for coupling to the carboxyl group of LA. To this aim, LA was activated as $\mathrm{N}$-hydroxysuccinimide (NHS) ester, and subsequently it was conjugated to MIMO via amide bond formation. The reaction product was purified by RP-HPLC (Figure S4), thus yielding MIMO@LA (yield 34\%).

\subsection{Electrochemical Characterization}

To verify whether MIMO retains its redox properties upon immobilization on the gold electrode, a comparison of the electrochemical properties of both the immobilized and freely diffusing enzyme was carried out using cyclic voltammetry (CV). The cyclic voltammogram of MIMO@LA immobilized onto the gold electrode, measured at $5.0 \mathrm{~V} / \mathrm{s}$ scan rate, is reported in Figure 2a. The voltammogram shows two well-defined peaks in the potential region between -700 and $100 \mathrm{mV}$ (vs. $\mathrm{Ag} / \mathrm{AgCl}$ ). The cathodic peak $\left(E_{\mathrm{pc}}\right)$ and the corresponding anodic peak on the reverse scan $\left(E_{\mathrm{pa}}\right)$ are located at $-391 \mathrm{mV}$ and $-313 \mathrm{mV}$ (vs. $\mathrm{Ag} / \mathrm{AgCl}$ ), respectively. For a detailed electrochemical analysis, CV scans were performed at various $v$, ranging from 0.1 to $10.0 \mathrm{~V} / \mathrm{s}$ (Figure $2 \mathrm{~b}$ ). The linear increase of the cathodic and anodic peak current $\left(\mathrm{I}_{\mathrm{p}}\right)$ with increasing scan rate (Figure 2c), confirmed the presence of a diffusion-less redox-active enzyme immobilized onto the electrode surface [37]. According to the literature, from the slope of the cathodic peak currents versus the scan rate it is possible to estimate the enzyme coverage of the functionalized electrode surface [67]. The coverage $\Gamma\left(\mathrm{mol} \cdot \mathrm{cm}^{-2}\right)$ of the functionalized electrode surface was estimated $20.4 \mathrm{pmol} \cdot \mathrm{cm}^{-2}$. This value is similar to the value of $23.5 \mathrm{pmol} \cdot \mathrm{cm}^{-2}$ obtained for the parent mimochrome adsorbed through hydrophobic interactions on a gold electrode coated with decane-1-thiol [52]. The peak potential separation $\left(\Delta \mathrm{E}_{\mathrm{p}}\right)$ of about $78 \mathrm{mV}$ indicates that the immobilized MIMO@LA undergoes a quasi-reversible electrochemical reaction [68]. The formal reduction potential $E^{\circ \prime}$ of the $\mathrm{Fe}(\mathrm{III}) / \mathrm{Fe}$ (II) couple, derived from the half-wave potential $E_{1 / 2}=\left(E_{\mathrm{pc}}+E_{\mathrm{pa}}\right) / 2$, was $-143 \pm 5 \mathrm{mV}$ vs. SHE and $-352 \mathrm{mV}$ vs. Ag/AgCl.

The cyclic voltammogram of the freely diffusing molecule measured at a scan rate of $5.0 \mathrm{~V} / \mathrm{s}$ (Figure S5) shows two well-defined current peaks. The cathodic and anodic peaks ( $E_{\mathrm{pc}}=-352 \mathrm{mV}$ and $E_{\mathrm{pa}}=-300 \mathrm{mV}$ vs. $\mathrm{Ag} / \mathrm{AgCl}$, respectively) are similar in shape and magnitude, with a current intensity ratio $\left(i_{\mathrm{pa}} / i_{\mathrm{pc}}\right)$ close to unity, and a $\Delta \mathrm{E}_{\mathrm{p}}$ in line with the expected theoretical value for a reversible mono-electronic process [68]. The formal reduction potential $E^{\circ \prime}$ was $-117 \pm 3 \mathrm{mV}$ (vs. SHE and $-326 \mathrm{mV}$ vs. $\mathrm{Ag} / \mathrm{AgCl}$. This value is in good agreement with those previously reported for MC6 and other freely diffusing mimochrome molecules [54,58].

The $E^{\circ \prime}$ value of the immobilized enzyme was found to be slightly more negative than for the freely diffusing enzyme. The observed small shift could be related to small changes in the environment occurring when the enzyme is covalently anchored on the surface. All these results demonstrated that MIMO retains its ability to exchange electrons with an electrode surface upon immobilization. Interestingly, the CVs remained essentially unchanged on consecutive potential cycling, thus indicating a good stability of the enzyme-modified electrode. 


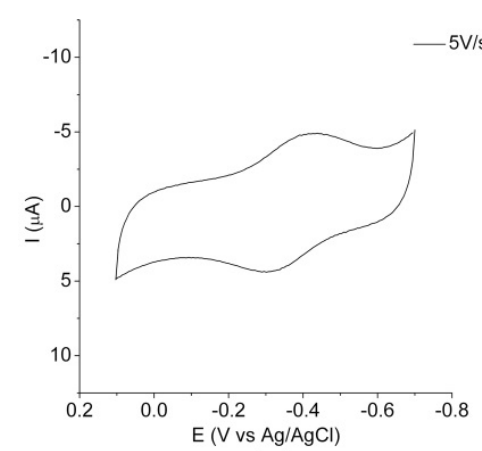

(a)

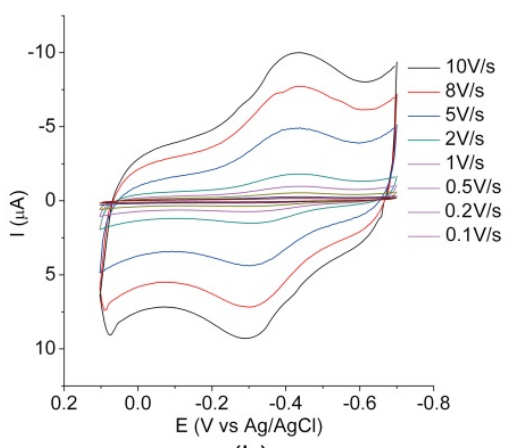

(b)

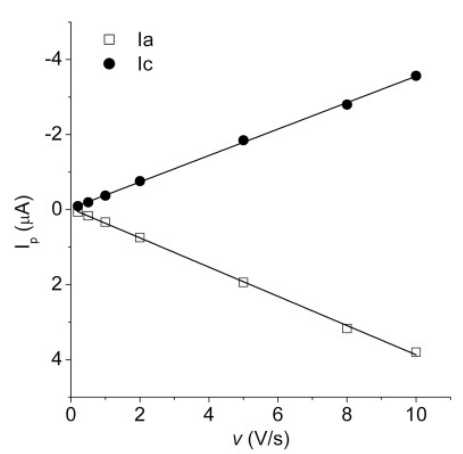

(c)

Figure 2. Electrochemical characterization of MIMO@LA. (a) Cyclic voltammograms for MIMO@LA on the gold electrode in $10.0 \mathrm{mM}$ phosphate buffer solution, $\mathrm{pH} 7.0$, at scan rate $(v) 5.0 \mathrm{~V} / \mathrm{s}$. Measurements are reported vs. $\mathrm{Ag} / \mathrm{AgCl}$ electrode. (b) Cyclic voltammograms for MIMO@LA on the gold electrode in $10.0 \mathrm{mM}$ phosphate buffer solution, $\mathrm{pH} 7.0$, recorded in the scan range 0.1-10.0 V/s. (c) Peak current intensity dependence $\left(\mathrm{I}_{\mathrm{p}}\right)$ versus $v$. $\mathrm{I}_{\mathrm{c}}$ and $\mathrm{I}_{\mathrm{a}}$ are the peak current intensities of the cathodic and anodic peaks, respectively.

\subsection{MIMO@LA Catalytic Activity on AuNPs}

\subsubsection{Synthesis and Characterization of MIMO@LA@AuNPs}

AuNPs were prepared in situ [69] by reduction of tetrachloroauric acid $\left(\mathrm{HAuCl}_{4}\right)$ in the presence of trisodium citrate, according to the Turkevich method [70]. The citrate-stabilized AuNPs were subsequently functionalized with MIMO@LA by ligand exchange reaction with the lipoic acid moiety. To control the density of the biomolecule on the AuNPs surface and reduce steric hindrance, a mixture of MIMO@LA and LA in dimethylsulfoxide (DMSO) (with a 6:1 LA:MIMO@LA ratio) was added to AuNPs-citrate in water ( $\mathrm{pH} 11)$. After incubation, the reaction mixture was centrifuged to remove excess of MIMO@LA and LA; the supernatant was decanted; and the pellet was resuspended in $\mathrm{NaOH}$ solution ( $\mathrm{pH}$ 11). This procedure of centrifugation/redispersion step was repeated several times. Complete removal of free MIMO@LA enzyme was ascertained by the absence of any catalytic activity in the supernatant (see Section 2.3.2). This procedure allowed obtaining the purified conjugate MIMO@LA@AuNPs, which was finally resuspended in $\mathrm{NaOH}$ solution ( $\mathrm{pH} 11$ ) and promptly used for subsequent experiments.

Conjugation of MIMO@LA to AuNPs was ascertained by Visible spectroscopy. Figure 3a reports the superposition of the visible spectra of citrate-stabilized AuNPs (red line) and of the MIMO@LA@AuNPs bioconjugate (blue line). Citrate-stabilized AuNPs showed the characteristic Surface Plasmon Resonance (SPR) band with a maximum at $522 \mathrm{~nm}$ [71]. As expected, conjugation of the artificial enzyme MIMO@LA to AuNPs caused a red-shift of the SPR band from 522 to $529 \mathrm{~nm}$. The SPR band is sensitive to refractive index changes in the proximity of the nanoparticle surface [71]. The observed red-shift, and no significant SPR band broadening is indicative that, upon MIMO@LA coating, AuNPs remained well dispersed without any aggregation in the colloidal suspension.

Figure 3 reports a comparison of the Transmission Electron Microscopy (TEM) images of citrate-stabilized AuNPs (Figure 3b) and MIMO@LA@AuNPs (Figure 3c), respectively. The citratestabilized AuNPs appeared uniform in size and shape, with an average diameter of $16 \pm 0.5 \mathrm{~nm}$, as assessed by the size distribution histogram (Figure S6a). TEM image of MIMO@LA@AuNPs, stained by $1 \%$ uranyl acetate [72] (Figure 3c), showed that, upon enzyme conjugation, the size of the AuNPs gold core was retained upon modification with MIMO@LA (Figure S6b). The presence of segregated patches of nanoparticle in the TEM images is due to the deposition process [73]. 


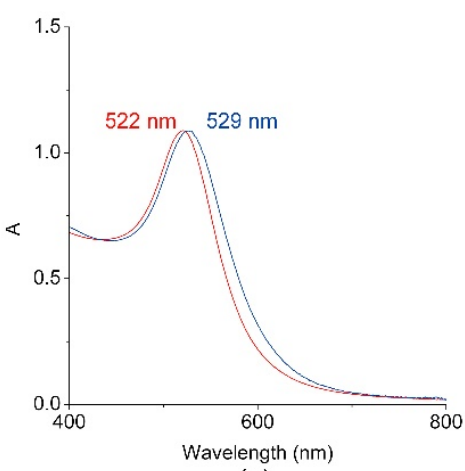

(a)

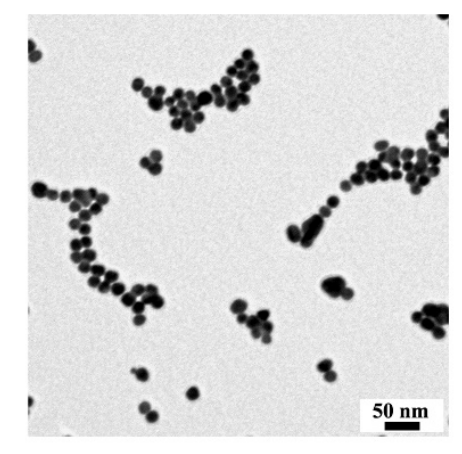

(b)

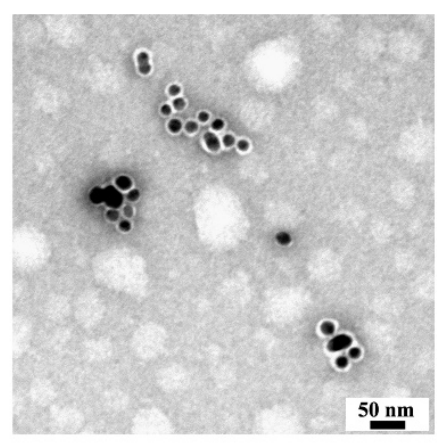

(c)

Figure 3. Characterization of MIMO@LA@AuNPs. (a) Visible spectra of citrate-capped AuNPs (red line) and of the bioconjugate MIMO@LA@AuNPs (blue line). (b) Transmission Electron Microscopy (TEM) image of citrate-capped AuNPs. (c) TEM image of the bioconjugate MIMO@LA@AuNPs. The staining with $1 \%$ uranyl acetate allowed highlighting the protein shell as a white halo around each AuNP.

An average diameter of $28 \pm 0.5 \mathrm{~nm}$ was measured for the MIMO@LA@AuNPs conjugate (Figure S6c), with a protein shell thickness of $5.0 \pm 0.5 \mathrm{~nm}$.

To quantify the amount of MIMO@LA loaded on each AuNPs, inductively coupled plasma mass spectrometry (ICP-MS) was used. The concentration of MIMO in the MIMO@LA@AuNPs solution was determined by quantifying the heme moiety on the basis of the total iron content of the sample $(10 \mu \mathrm{M})$. Given an AuNPs concentration of $8 \mathrm{nM}$ (see Materials and Methods), an average loading of $\cong 1200$ MIMO molecules per nanoparticle was obtained.

The maximum theoretical number of protein molecules $\left(N_{\max }\right)$ that can be loaded on each spherical AuNP was calculated through geometrical considerations, as previously reported by Mattoussi et al. [74], using the following equation:

$$
N_{\text {max }}=0.65 \times \frac{\left(R_{\text {complex }}^{3}-R_{\text {AuNP }}^{3}\right)}{R_{\text {protein }}^{3}}
$$

where $R_{\text {complex }}$ is the AuNP-protein complex radius, $R_{\text {AuNP }}$ is the gold nanoparticle radius, and $R_{\text {protein }}$ is the radius of the protein. This equation takes into account the filling factor for hard sphere, calculated to be 0.65 [75]. $R_{\text {AuNP }}$ comprises the sum of the AuNP radius ( $8 \mathrm{~nm}$, as obtained from TEM data) and the thickness of the layer composed by the side chain of Lys residue and LA (estimated to be around $2 \mathrm{~nm}$, by considering both chains in an all-trans extended conformation, see Figure S7). $R_{\text {complex }}$ comprises the sum of $\mathrm{R}_{\mathrm{AuNP}}$ and the diameter of the MIMO protein. Looking at the model structure (see Figure S7), MIMO molecule has a cylindrical shape, with dimensions of $1.6 \mathrm{~nm}$ in diameter and $2.6 \mathrm{~nm}$ in length. To take into account all possible randomly oriented cylinder molecules with respect to the AuNP, the radius of gyration $\left(R_{G}\right)$ [76] for MIMO was calculated (see Materials and Methods), and the value of $2 \times R_{\mathrm{G}}(1.8 \mathrm{~nm})$ was used for MIMO diameter in the calculation of $R_{\text {complex }}$. This calculation afforded an estimated theoretical number $\left(N_{\max }\right)$ of $\cong 570 \mathrm{MIMO}$ per nanoparticle. This value is almost half of that obtained from experiments ICP-MS analysis (MIMO:AuNP $\cong 1200$ ). Furthermore, the calculated MIMO diameter $(1.8 \mathrm{~nm})$ is almost half of protein shell thickness measured by TEM. Thus, these analyses suggest the formation of a MIMO double layer around each AuNP, likely due to protein-protein interactions.

\subsubsection{Catalytic Activity of MIMO@LA@AuNPs}

To verify whether MIMO acts as a competent catalyst even upon immobilization onto AuNPs, the peroxidase activity of the conjugate was assayed, using 2,2'-azino-bis (3-ethylbenzothiazoline6-sulphonic acid) (ABTS) as substrate and $\mathrm{H}_{2} \mathrm{O}_{2}$ as oxidizing agent, under the optimal experimental 
conditions (50 mM phosphate buffer $\mathrm{pH}$ 6.5, 50\% 2,2,2-trifluoroethanol (TFE) $v / v$ ) previously found for mimochromes $[24,50,54]$.

It should be noticed that both stability of the AuNPs colloidal dispersion and catalytic performances strongly depend on $\mathrm{pH}$. Thus, the optimal $\mathrm{pH}$ for colloidal stability could be sometimes far from the optimal pH range for catalysis [77]. In the case of MIMO@LA@AuNPs conjugate, colloidal stability is retained when the conjugate is placed in the environmental condition optimized for enzyme catalysis. In fact, no significant changes were observed in the visible spectra of the colloidal suspension, apart from a small blue-shift $(2 \mathrm{~nm})$ of the SPR band absorbance maximum, probably due to the presence of TFE (Figure S8).

Catalytic assays were first aimed at verifying that the activity of the conjugate was only related to the AuNPs immobilized form of the artificial MIMO enzyme. To this aim, a kinetic control assay was done after various centrifugation cycles, on both the supernatant and on the resuspended pellet. Figure 4 shows the progress curve for the oxidation of ABTS, catalyzed by the AuNP-immobilized enzyme, by following the absorbance of the oxidation product ABTS radical cation (ABTS ${ }^{+}$) at $660 \mathrm{~nm}$ as a function of time. Significant activity was detected only in the nanoparticles resuspended pellet, containing MIMO@LA@AuNPs. In the supernatant, activity is near to background autoxidation levels. This demonstrated that the catalyst was immobilized onto nanoparticles, and confirmed the absence of free MIMO@LA enzyme in solution.

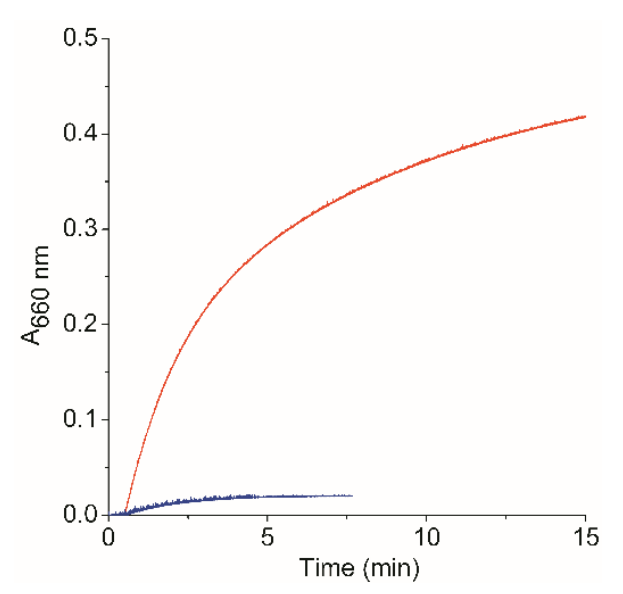

Figure 4. Catalytic activity of MIMO@LA@AuNPs. Time-dependent absorption at $660 \mathrm{~nm}$ of ABTS ${ }^{+\bullet}$ during ABTS oxidation, as observed in the resuspended pellet (red curve) and the supernatant (blue curve) of the MIMO@LA@AuNPs solution, after centrifugation. Reaction conditions were: $5.0 \mathrm{mM}$ ABTS and $10.0 \mathrm{mM} \mathrm{H}_{2} \mathrm{O}_{2}$ in $50.0 \mathrm{mM}$ phosphate buffer $\mathrm{pH}$ 6.5, 50\% 2,2,2-trifluoroethanol (TFE) (v/v).

This result is a first evidence that the artificial MIMO enzyme is still active when conjugated to the AuNPs. To obtain a detailed kinetic analysis of the MIMO@LA@AuNPs conjugate, the kinetic parameters of the enzyme were determined by varying $\mathrm{H}_{2} \mathrm{O}_{2}$ concentration using fixed concentrations of ABTS, and vice versa, in the same conditions used for the previous experiment. The initial rates of ABTS oxidation $\left(v_{0}\right)$ were plotted as a function of both substrate concentrations (Figure 5 ). Interestingly, the enzyme activity followed a typical Michaelis-Menten kinetics, as observed for the freely diffusing enzyme (Figure S9). 


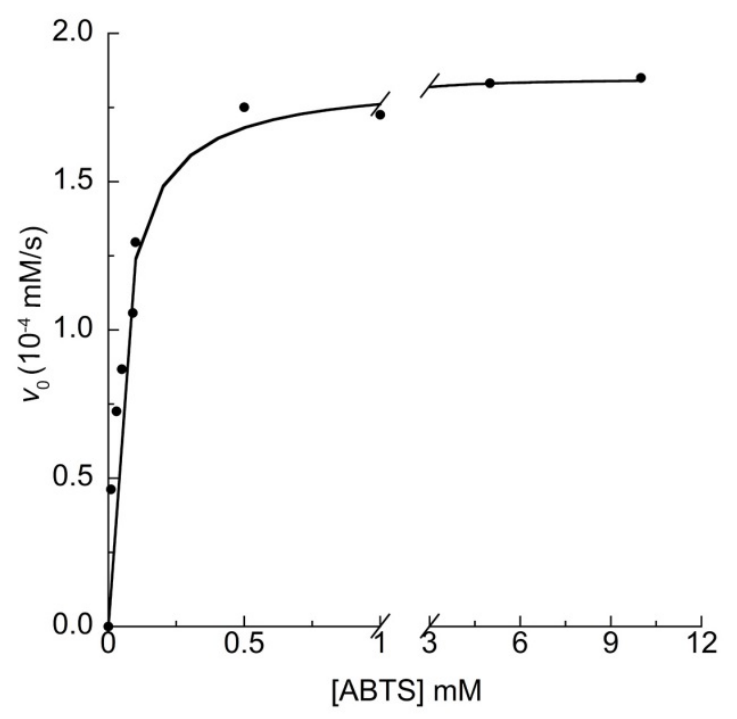

(a)

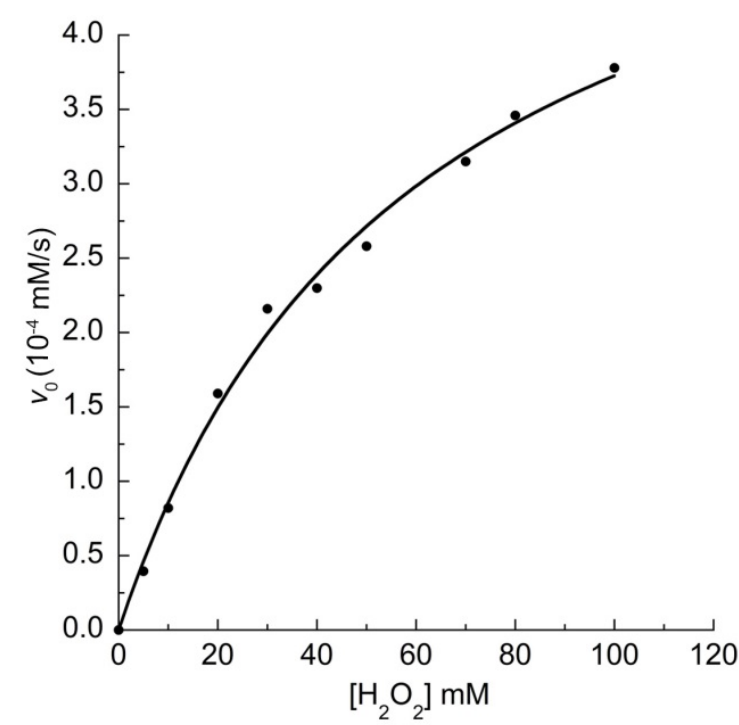

(b)

Figure 5. Peroxidase activity of MIMO@LA@AuNPs: (a) initial rate dependence towards ABTS concentration; and (b) initial rate dependence towards $\mathrm{H}_{2} \mathrm{O}_{2}$ concentration. Reaction conditions were: 50.0 mM phosphate buffer pH 6.5 50\% TFE ( $v / v)$; MIMO@LA@AuNPs enzyme concentration $3.5 \times 10^{-7} \mathrm{M}$. For the experiments performed at variable ABTS (a), the $\mathrm{H}_{2} \mathrm{O}_{2}$ concentration was $30.0 \mathrm{mM}$. For the experiments performed at variable $\mathrm{H}_{2} \mathrm{O}_{2}(\mathbf{b})$, the ABTS concentration was fixed at $5.0 \mathrm{mM}$.

Table 1 reports the $k_{\text {cat }}$ (turnover frequency) and $K_{\mathrm{M}}$ (Michaelis-Menten constant) values for the ABTS oxidation, determined for both the immobilized and free enzyme. In the freely diffusing form, MIMO shows a catalytic activity comparable to that of the previous analog MC6 [50]. A decrease in the $k_{\text {cat }}$ value together with a slight increase in the $K_{\mathrm{M}}$ values was instead observed when comparing the suspension of MIMO@LA@AuNPs to the freely diffusing enzyme.

Table 1. Kinetic parameters for $\mathrm{H}_{2} \mathrm{O}_{2}$ dependent oxidation of ABTS by MIMO@LA@AuNPs. The data for the free MIMO enzyme are also reported for comparison ( $k_{\text {cat }}$ : turnover frequency; $K_{\mathrm{M}}$ : Michaelis-Menten constant; MC6: Fe(III)-Mimochrome VI).

\begin{tabular}{cccc}
\hline Compound & $\boldsymbol{k}_{\text {cat }}\left(\mathbf{s}^{-\mathbf{1}}\right)$ & $\boldsymbol{K}_{\mathbf{M}}$ ABTS $\mathbf{( \mathbf { 1 0 } ^ { - \mathbf { 5 } } \mathbf { M } )}$ & $\boldsymbol{k}_{\mathrm{cat}} / \boldsymbol{K}_{\mathbf{M}}\left(\mathbf{m M}^{\mathbf{- 1}} \cdot \mathbf{s}^{-\mathbf{1}}\right)$ \\
\hline MIMO@LA@AuNPs & $1.7 \pm 0.1$ & $14.7 \pm 0.1$ & 11.5 \\
MIMO & $468 \pm 27$ & $12.5 \pm 2$ & $3743 \pm 814$ \\
MC6 $^{\S}$ & $371 \pm 14$ & $8.4 \pm 0.2$ & $4417 \pm 197$ \\
\hline \multicolumn{2}{r}{ § from Ref. }
\end{tabular}

This result, although unfavorable, is not surprising. In fact, the catalytic efficiency of natural enzymes can broadly change upon immobilization onto different surfaces and/or AuNPs [36,78,79].

For example, the effect of the immobilization and/or conjugation to nanoparticles in enhancing or reducing the catalytic activity, relatively to the freely diffusing enzyme, has been deeply analyzed for horseradish peroxidase (HRP) [80-82]. In particular, the effect of the hydrodynamic diameter and nanoparticle curvature on the reactivity of HRP when conjugated to AuNPs has recently been reported [82]. Similar to our system, HRP showed reduced catalytic activity toward ABTS oxidation, and this finding was demonstrated to strongly correlate with the size of AuNPs. Indeed, the $k_{\text {cat }}$ value decreases when moving from the free enzyme $\left(800 \mathrm{~s}^{-1}\right)$ to the AuNP-HRP bioconjugate as a function of AuNPs diameter (AuNP-HRP diameter $25 \mathrm{~nm} ; k_{\text {cat }}: 500 \mathrm{~s}^{-1}$; AuNP-HRP diameter $40 \mathrm{~nm}, k_{\text {cat }}: 200 \mathrm{~s}^{-1}$ ). Moreover, the $K_{\mathrm{M}}$ value for ABTS doubled upon HRP conjugation (free HRP, $K_{\mathrm{M}} \cong 3 \mathrm{mM}$; AuNP-HRP diameter $18 \mathrm{~nm}, K_{\mathrm{M}} \cong 5.5 \mathrm{mM}$ ) [82]. Diffusion-collision theory coupled with experimental studies allowed to hypothesizing that two main factors affect the catalytic parameters of these AuNP-HRP 
bioconjugates: (1) influence of the bioconjugate sizes on the diffusion kinetics, which impacts the $k_{\text {cat }}$ values; and (2) changes in the secondary structures of the HRP active site, depending on the AuNP curvature, which affects $K_{M}$ values.

Changes in the kinetic performances of enzymes upon immobilization onto AuNPs have been also related to enzyme multilayer formation [83]. Even though enzyme accumulation and crowding onto AuNPs could have favorable effects on enzyme kinetics, due to the stabilization of both the enzyme active conformation and colloidal suspension, they can also have negative effects [83]. When enzyme multilayer formation occurs, the activity of enzymes in the inner layers can be affected by the poor accessibility of substrates, by the competition with substrates of the outer layer enzymes and/or by inhibition of enzyme conformational changes during catalysis for steric hindrance [83].

According to these previously reported results, we hypothesize that the observed reduction of MIMO catalytic efficiency upon immobilization onto AuNPs is related to the MIMO double layer formation around each AuNP (see previous section). This hypothesis is supported by preliminary results obtained on a different MIMO@LA@AuNPs conjugate preparation, in which the size of AuNPs was decreased (13 nm diameter, data not shown). In this preparation, to reduce MIMO multilayer formation, the synthetic procedure included, as final step in the conjugation procedure, a prolonged washing step with TFE on the MIMO@LA@AuNPs conjugate. This washing procedure was performed because, thanks to the high solvation properties of TFE and solubility of MIMO in this solvent, it could inhibit MIMO-MIMO interactions and/or aggregation on the AuNP surface, thus disfavoring multilayer formation. Indeed, in this preparation, conjugation of MIMO@LA to AuNP was found to afford an average loading of $\cong 470 \mathrm{MIMO}$ molecules per nanoparticle, close to the maximum theoretical number of protein molecules expected for a monolayer formation $\left(N_{\max }=570\right.$, see above).

Remarkably, this conjugate displayed higher kinetic parameters than those for the multilayer preparation, with an almost ten-fold increase of the $k_{\text {cat }}$ value $\left(k_{\text {cat }}=15.2 \pm 2 \mathrm{~s}^{-1} ; K_{\mathrm{M}}=25.5 \pm 6 \times 10^{-5} \mathrm{M}\right.$; $\mathrm{k}_{\mathrm{cat}} / \mathrm{K}_{\mathrm{M}}=59.6 \pm 20 \mathrm{mM}^{-1} \mathrm{~s}^{-1}$ ), and only 30 -fold decrease from the freely diffusing MIMO. Assuming that, in the double-layer MIMO@LA@AuNPs conjugate, only the outermost enzyme layer is the active one, the measured $k_{\text {cat }}$ value could only double $\left(k_{\text {cat }} \cong 3.4 \mathrm{~s}^{-1}\right)$. Even with this assumption, $k_{\text {cat }}$ does not reach the value obtained for the monolayer preparation, thus suggesting that multilayer formation negatively influenced the catalyst performances. We cannot exclude that other factors such as influence of the bioconjugate sizes on the diffusion kinetics, limited diffusion of the substrates to the active site, partial loss of the catalyst active structure, and length of the linker could influence the variations in the catalytic parameters of MIMO when conjugated to the AuNPs. A deep study on the factors affecting the catalytic parameters of the MIMO enzyme when conjugated to AuNPs is underway.

Interestingly, the overall results strongly support the feasibility of using mimochrome artificial peroxidases for the development of AuNP-based biomaterials. It should be highlighted that the presence of the MIMO@LA coating layer positively impacts the colloidal stability, even at neutral/slight acidic $\mathrm{pH}$ conditions. This represents a key point in the preparation and use of enzyme-AuNP conjugates to avoid AuNP coalescence while preserving enzyme activity.

\section{Materials and Methods}

All solvents, used in the synthesis and purification, were anhydrous and HPLC grade, respectively, and were supplied by Romil (Cambridge, UK). All buffer solutions were made by using water with a HPLC purity grade (Romil); phosphate salts (monobasic and dibasic) for buffers preparation, NHS, THF (tetrahydrofuran), uranyl acetate dihydrate and $\mathrm{H}_{2} \mathrm{O}_{2}(30 \%, v / v)$ were provided by Fluka; TFE was supplied from Romil. The DCC ( $N, N^{\prime}$-Dicyclohexylcarbodiimide) as well as $\mathrm{HAuCl}_{4}$ solution $(30 \% w / w)$ were obtained from Sigma Aldrich (Taufkirchen, Germany). The electrodes, the electrochemical cell, the alumina and the diamond powder for cleaning the electrodes are from BASi (West Lafayette, IN, USA).

Iron content of MIMO@LA@AuNPs solution was quantified by ICP-MS analysis, using Aurora Bruker M90 instrumentation (Bremen, Germany). Aqua regia digestion procedure $\left(90^{\circ} \mathrm{C}\right.$, overnight) 
was adopted for organic component and gold degradation. Iron concentration was estimated at $0.55 \mathrm{mg} / \mathrm{L}\left(\sim 9.85 \times 10^{-6} \mathrm{M}\right)$. UV-vis analysis was performed on Cary Varian 50 Probe UV Spectrophotometer (Varian, Palo Alto, CA, USA). In all analyses, $1 \mathrm{~cm}$ path length quartz cuvettes were used. All the data were analyzed by using the Origin Pro 8 (Origin Lab Corporation, Northampton, MA, USA) and the Kaleidagraph software (version 4.1.1, Synergy Software, Reading, PA, USA).

\subsection{Synthesis of MIMO@LA}

MIMO was modified at the side chain of Lys11 with lipoic acid to allow its subsequent conjugation to AuNPs. To this aim, the carboxyl group of LA was first activated as NHS ester, by using dicyclohexylcarbodiimide (DCC) and NHS in THF. To a $38.8 \mathrm{mM}$ solution of LA ( $23.9 \mathrm{mg}, 0.116 \mathrm{mmol})$ in $3.0 \mathrm{~mL}$ of THF at $0{ }^{\circ} \mathrm{C}, 1$ equivalent of NHS $(13.3 \mathrm{mg}, 0.116 \mathrm{mmol})$ and 1 equivalent of DCC $(23.9 \mathrm{mg}$, $0.116 \mathrm{mmol}$ ) were added. The reaction mixture was kept under nitrogen and stirred for $30 \mathrm{~min}$ at $0{ }^{\circ} \mathrm{C}$, and then allowed to react for $48 \mathrm{~h}$ at room temperature. The reaction product was purified by means of centrifugation cycles, to remove dicyclohexylurea (DCU). In a first step, the DCU was removed and the supernatant solution was dried under vacuum. The pellet was then dissolved in acetone, and the solution centrifuged to remove residual DCU. This procedure was repeated for five cycles. Finally, the product was obtained as a yellow solid upon recrystallization from acetone/hexane $(1 / 4 v / v)$. In total, $15.25 \mathrm{mg}$ ( $43.4 \%$ yield) of the $N$-hydroxysuccinimidyl lipoate were obtained. The $N$-hydroxysuccinimidyl lipoate was then added to MIMO in dimethylformammide (DMF) solution, to give MIMO@LA. Next, $15.0 \mathrm{mg}$ of MIMO (3.88 $\mu \mathrm{mol}, 1.29 \mathrm{mM})$ were allowed to react with 10 equivalents $(11.7 \mathrm{mg}, 38.8 \mu \mathrm{mol}, 12.9 \mathrm{mM})$ of $N$-hydroxysuccinimidyl lipoate in DMF $(3.0 \mathrm{~mL})$, in the presence of 4 equivalents of diisopropylethylamine (DIEA). The mixture was allowed to react overnight. The reaction product was purified by RP-HPLC, and purity and the identity of the product was determined by RP-HPLC-ESI-MS (see Supplementary Materials). The chromatographic profile of the reaction product showed the presence of a main peak with a $t_{R}=25.6 \mathrm{~min}$ (Figure $\mathrm{S} 4$ ). ESI-MS mass analysis allowed identifying the product as the desired MIMO@LA (experimental mass 3709.2 Da, theoretical mass 3709.53 Da). The product was obtained with a $34.0 \%$ yield.

\subsection{Synthesis and Characterization of MIMO@LA@AuNPs}

Citrate-stabilized gold nanoparticles (AuNPs) were prepared by citrate reduction of $\mathrm{HAuCl}_{4}$ according to the procedure developed by Turkevich [70]. An aqueous solution of $\mathrm{HAuCl}_{4}(1 \mathrm{mM}$, $25.5 \mathrm{~mL}$ ) was brought to boil, and then kept at reflux under stirring for $10 \mathrm{~min}$. Once the gold solution was vigorously refluxing, an aqueous solution of sodium citrate $(39 \mathrm{mM}, 2.54 \mathrm{~mL})$ was added quickly. Upon the addition of the sodium citrate, the color of the solution turned ruby-red, indicating the formation of the gold nanoparticles. The suspension was allowed to heat for additional $30 \mathrm{~min}$ with vigorous stirring. The suspension was then allowed to cool to room temperature. The AuNPs solution was stored at $4{ }^{\circ} \mathrm{C}$ in the dark for subsequent uses.

Conjugation of MIMO@LA to AuNPs was obtained by substitution of the citrate ligands with lipoic acid, following the procedure reported by Onoda et al. [65]. The $\mathrm{pH}$ of the stock citrate-stabilized AuNPs solution was adjusted to 11 with the dropwise addition of $1 \mathrm{M} \mathrm{NaOH}$. To $2.8 \mathrm{~mL}$ of this stock solution (AuNPs concentration $\cong 8 \mathrm{nM}$ ), a mixture of MIMO@LA $\left(0.600 \mathrm{mg}, 1.62 \times 10^{-4} \mathrm{mmol}\right.$, in $400 \mu \mathrm{L})$ and LA $\left(0.204 \mathrm{mg}, 9.93 \times 10^{-4} \mathrm{mmol}\right.$, in $13.6 \mu \mathrm{L}$ of $15 \mathrm{mg} / \mathrm{mL}$ solution) in DMSO (LA:MIMO@LA ratio $\cong 6: 1$ ) was added. The solution was incubated at room temperature in the dark, and the proceeding of the reaction was followed by UV-Vis analysis, evaluating the shift in the SPR band upon MIMO@LA conjugation. After $3 \mathrm{~h}$, the solution was centrifuged at 12,000 rpm for $25 \mathrm{~min}$ at $4{ }^{\circ} \mathrm{C}$. To remove excess MIMO@LA and LA, the supernatant was decanted and the remaining pellet was re-dispersed in $\mathrm{NaOH}$ solution ( $\mathrm{pH}$ 11). This procedure was repeated three times to obtain purified MIMO@LA@AuNPs. The pellet was then resuspended in $\mathrm{NaOH}$ solution ( $\mathrm{pH} 11)$, and promptly used for subsequent experiments. 


\subsection{MIMO Radius of Gyration Calculation}

The radius of gyration $\left(R_{G}\right)$ [76] for MIMO molecule was calculated on the model structure (see Figure S7), by using the following equation:

$$
R_{G}=\sqrt{\frac{1}{N}} \sum_{i=1}^{N}\left(\vec{x}_{i}-\vec{x}\right)^{2}
$$

where $\vec{x}_{i}$ is the position of the atom $i$ in the model structure, $x$ is the position of the centroid of the molecule, and $N$ is the total number of non-hydrogen atoms. Calculation afforded a value of $9.03 \AA$ $(0.903 \mathrm{~nm})$ for MIMO $R_{G}$ value.

\subsection{AuNPs Physico-Chemical Characterization}

Transmission electron microscopy (TEM) images were obtained in the bright-field mode using a Philips EM $208 S$ TEM (Philips, Eindhoven, The Netherlands), with an accelerating voltage of $100 \mathrm{kV}$. The samples were prepared by evaporating two drops $(5 \mu \mathrm{L})$ of either AuNPs or MIMO@LA@AuNPs solutions onto carbon-coated copper grid (200 mesh) and allowing them to dry at room temperature overnight. To observe the protein shell by TEM, MIMO@LA@AuNPs conjugates were analyzed upon negative staining with $1 \%$ uranyl acetate. The histograms of the particle size distribution and the average particle diameter were calculated from the TEM images by using ImageJ software (National Institutes of Health, available free of charge at Web site rsb.info.nih.gov/ij/). At least 50 independent measurements were taken at different locations of the TEM images of the samples. The measurements were also confirmed by repeating the analysis on TEM images of independent samples.

Concentrations of the prepared AuNPs solution was estimated as reported in the literature [84]. By assuming that all the initial gold is incorporated into spherical particles with the density of the bulk gold $\left(\rho_{\text {gold }}=19 \mathrm{~g} / \mathrm{cm}^{3}\right)$ [85], AuNPs concentration can be obtained by dividing the initial $1 \mathrm{mM}$ concentration of atomic gold by the following equation:

$$
\frac{4}{3} \pi r^{3} \frac{\rho_{\text {gold }}}{A W_{\text {gold }}} \mathrm{A}
$$

where $r$ is the average radius of the particles from TEM data, $\mathrm{A}$ is Avogadro's number, and $A W_{\text {gold }}$ is the atomic weight of gold $(197.97 \mathrm{~g} / \mathrm{mol})$. By considering $r=8.0 \mathrm{~nm}$, as derived from TEM analysis, AuNPs concentration was assessed to be $8.06 \mathrm{nM}$.

The concentration of AuNPs in the stock solution was also determined directly from UV-vis spectra, by using the method reported by Fernig and coworkers [86]. As reported, the ratio of the absorbance at the SPR band ( $\left.\mathrm{A}_{\mathrm{SPR}}\right)$ to the absorbance at $450 \mathrm{~nm}\left(\mathrm{~A}_{450}\right)$ can give an indication of the AuNPs diameter. For an $A_{S P R} / A_{450}$ ratio of 1.64, the diameter of AuNPs was calculated to be $\cong 16 \mathrm{~nm}$, in good agreement with TEM data (Figure S6a). From the value of $\mathrm{A}_{450}$ and using the calculated extinction coefficient $\varepsilon_{450}$ of $2.67 \times 10^{8} \mathrm{M}^{-1} \mathrm{~cm}^{-1}$, AuNPs concentration in the stock solution was estimated to be $7.43 \mathrm{nM}$, in good agreement with the previous calculation.

\subsection{Voltammetric Analysis}

All cyclic voltammetry experiments were performed with a Potentiostat/Galvanostat $\mu$ AUTOLAB Type III (Ecochemie, Utrecht, The Netherlands) using a three-electrode cell for small volume samples (0.5-1 mL) purchased from BASi, under argon. Temperature controlled measurements were conducted using a thermo-cryostat R2 (Grant Instruments, Cambridge, UK). For all voltammetric analyses, argon gas was purged through the solution for at least $20 \mathrm{~min}$ to remove any dissolved oxygen before every experiment. An argon atmosphere was maintained over the solution during the measurements. A $3 \mathrm{~mm}$-diameter GCE was used as working electrode, for the freely diffusing species. Measurements were carried out in $5.0 \mathrm{mM}$ phosphate buffer, $\mathrm{pH} 7.0$, with $100 \mathrm{mM} \mathrm{NaClO}_{4}$ as the supporting electrolyte. 
For electrochemical measurements of the immobilized enzyme, MIMO@LA was immobilized onto a $1.6 \mathrm{~mm}$-diameter polycrystalline gold electrode through covalent binding via S-Au bond of the LA moiety. A clean gold electrode was immersed into a freshly prepared 9.0 mM solution of MIMO@LA in ethanol/water $75 / 25(v / v)$ for $48 \mathrm{~h}$ at $4{ }^{\circ} \mathrm{C}$. The electrode was rinsed with deionized water and then immersed into phosphate buffer solution (10.0 mM, pH 7.0) for electrochemical measurements.

Platinum wire and $\mathrm{Ag} / \mathrm{AgCl}(3.0 \mathrm{M} \mathrm{NaCl})$ electrodes were used as counter and reference electrode, respectively. A Vycor (PAR) set ensured the electric contact between the $\mathrm{Ag} / \mathrm{AgCl}$ electrode and the working solution. Glassy carbon electrodes were polished mechanically with an abrasive alumina powder [87]. Gold electrodes were treated with $\mathrm{HNO}_{3} 3 \mathrm{M}$, by dropping $5 \mu \mathrm{L}$ of the acid on the surface of the electrode. After $15 \mathrm{~min}$, electrodes were rinsed thoroughly with deionized water, and then the same polishing procedure described above for GCE was applied. The degree of polishing of gold electrodes was evaluated by looking at the difference in the peak potential for the redox couple of Ferri/Ferrocyanide, which is expected to be close to $60 \mathrm{mV}$ [88]. A $10 \mathrm{mM}$ ferricyanide solution in ethanol/0.1 $\mathrm{M} \mathrm{NaClO}_{4} 50 / 50(v / v)$ was used to register a cyclic voltammogram at a scan rate of $0.05 \mathrm{~V} / \mathrm{s}$. The estimation of the surface coverage of the electrode was made according to literature methods [67]. According to this method, the peak current $\left(I_{p}\right)$ is related to the surface concentration of the electroactive species, $\Gamma$, by the following equation:

$$
I_{p}=\frac{n^{2} F^{2} A \Gamma v}{4 R T}
$$

where $n$ represents the number of electrons involved in the reaction, $A$ is the surface area $\left(2.01 \times 10^{-2} \mathrm{~cm}^{2}\right)$ of the electrode, $\Gamma\left(\mathrm{mol} \cdot \mathrm{cm}^{-2}\right)$ is the surface coverage, and the other symbols have their usual meanings. From the slope of the anodic peak currents versus the scan rate (Figure 2c), the calculated surface concentration was $20.4 \mathrm{pmol} \cdot \mathrm{cm}^{-2}$ for $n=1$.

\subsection{Catalytic Assays}

The catalytic activity of the MIMO@LA@AuNPs was assayed as for the freely diffusing enzyme. All the reactions were carried out in phosphate buffer $(50 \mathrm{mM}, \mathrm{pH} 6.5)$, in the presence of $50 \%$ TFE $(v / v)$. All the catalytic experiments were followed using a Varian Cary 50 spectrophotometer, by using ABTS [89] as substrate. The change in absorbance of the ABTS ${ }^{+\bullet}$ cation radical was followed at $660 \mathrm{~nm}$ $\left(\lambda_{\max }=660 \mathrm{~nm}, \varepsilon_{660}=1.40 \times 10^{4} \mathrm{M}^{-1} \mathrm{~cm}^{-1}\right)$. Kinetic parameters were determined by varying $\mathrm{H}_{2} \mathrm{O}_{2}$ concentration using fixed concentrations of reducing substrate, and vice versa.

In the experiments performed at variable $\mathrm{H}_{2} \mathrm{O}_{2}$ concentration (in the range 1.0-100 mM), the ABTS concentration was kept constant at $5.0 \mathrm{mM}$. In the experiments performed at variable ABTS concentration (in the range $0.01-10.0 \mathrm{mM}$ ) the $\mathrm{H}_{2} \mathrm{O}_{2}$ concentration was $30 \mathrm{mM}$. For the freely diffusing experiments MIMO concentration was $2.0 \times 10^{-7} \mathrm{M}$ and reaction volume was $1.0 \mathrm{~mL}$. For the MIMO conjugated to AuNPS, in a typical assay, $33.0 \mu \mathrm{L}$ of the MIMO@LA@AuNPs solution were diluted to a final volume of $1.0 \mathrm{~mL}$ to afford a $3.2 \times 10^{-7} \mathrm{M}$ concentration of the enzyme. The kinetic parameters were determined using the two-substrate Michaelis-Menten kinetic model [90]. Data were analyzed using the following equation:

$$
v=\frac{[E]_{0}}{\frac{1}{k_{c a t}}+\frac{K_{M_{A}}}{k_{c a t}[A]}+\frac{K_{M_{B}}}{k_{c a t}[B]}}
$$

where $v$ is the initial rate, $[E]_{0}$ is the enzyme concentration, $[A]$ is the $\mathrm{H}_{2} \mathrm{O}_{2}$ concentration, and $[B]$ is the ABTS concentration.

\section{Conclusions}

In this work, we demonstrated that artificial peroxidases such mimochromes are promising candidates to be used for different applications as immobilized enzymes. Through the modification 
of the MIMO artificial enzyme with a specific linker such LA, a redox- and catalytically-active biomolecular component can be easily and rapidly grafted onto different surfaces such as gold electrodes or AuNPs. Upon immobilization onto gold electrode, MIMO@LA produced a hybrid interface allowing for direct electron transfer between the electrode and the redox-active heme-center. This behavior is very important for the future development of mimochrome-modified electrode surfaces useful in the construction of electrochemical biosensors. Further, conjugation of MIMO@LA to AuNPs afforded catalytically active MIMO@LA@AuNPs. Even though a decrease in MIMO catalytic efficiency was observed upon conjugation, these results represent a proof of concept in employing mimochrome artificial peroxidases as bioactive component of AuNP-based biomaterials. The use of artificial enzymes will expand the collection and the applicability of gold-based biomaterials, because the biomolecular component can be tailored to specific functions. In conclusion, this study is prodromal to the development of new gold-based biomaterials, which can find applications in catalysis, biosensors and immune-enzymatic diagnostic assays.

Supplementary Materials: Supplementary Materials can be found at http:/ /www.mdpi.com/1422-0067/19/10/ 2896/s1.

Author Contributions: Conceptualization, F.N. and A.L.; Data curation, G.Z. and F.N.; Formal analysis, E.R. and M.C.; Funding acquisition, A.L.; Investigation, G.Z. and A.M.; Methodology, G.Z., E.R. and A.M.; Supervision, A.L.; Validation, O.M., V.P., F.N. and A.L.; Writing—original draft, F.N.; and Writing—review and editing, O.M., V.P. and A.L.

Funding: This work was supported by Progetto PON/MIUR 01_01585.

Acknowledgments: Angela Amoresano and Francesca Pane are kindly acknowledged for their support for ICP-MS analysis, and Fabrizia Sibillo for her technical assistance.

Conflicts of Interest: The authors declare no conflict of interest.

\section{References}

1. Nastri, F.; Chino, M.; Maglio, O.; Bhagi-Damodaran, A.; Lu, Y.; Lombardi, A. Design and engineering of artificial oxygen-activating metalloenzymes. Chem. Soc. Rev. 2016, 45, 5020-5054. [CrossRef] [PubMed]

2. Grayson, K.J.; Anderson, J.L.R. The ascent of man (made oxidoreductases). Curr. Opin. Struct. Biol. 2018, 51, 149-155. [CrossRef] [PubMed]

3. Hyster, T.K.; Ward, T.R. Genetic optimization of metalloenzymes: Enhancing enzymes for non-natural reactions. Angew. Chem. Int. Ed. 2016, 55, 7344-7357. [CrossRef] [PubMed]

4. Schwizer, F.; Okamoto, Y.; Heinisch, T.; Gu, Y.; Pellizzoni, M.M.; Lebrun, V.; Reuter, R.; Köhler, V.; Lewis, J.C.; Ward, T.R. Artificial metalloenzymes: Reaction scope and optimization strategies. Chem. Rev. 2017, 118, 142-231. [CrossRef] [PubMed]

5. Lewis, J.C. Artificial metalloenzymes and metallopeptide catalysts for organic synthesis. ACS Catal. 2013, 3, 2954-2975. [CrossRef]

6. Mocny, C.S.; Pecoraro, V.L. De novo protein design as a methodology for synthetic bioinorganic chemistry. Acc. Chem. Res. 2015, 48, 2388-2396. [CrossRef] [PubMed]

7. Yu, F.; Cangelosi, V.M.; Zastrow, M.L.; Tegoni, M.; Plegaria, J.S.; Tebo, A.G.; Mocny, C.S.; Ruckthong, L.; Qayyum, H.; Pecoraro, V.L. Protein design: Toward functional metalloenzymes. Chem. Rev. 2014, 114, 3495-3578. [CrossRef] [PubMed]

8. Bhagi-Damodaran, A.; Hosseinzade, P.; Mirts, E.; Reed, J.; Petrik, I.D.; Lu, Y. Design of heteronuclear metalloenzymes. Methods Enzymol. 2016, 580, 501-537. [CrossRef] [PubMed]

9. Jeschek, M.; Panke, S.; Ward, T.R. Artificial metalloenzymes on the verge of new-to-nature metabolism. Trends Biotechnol. 2018, 36, 60-72. [CrossRef] [PubMed]

10. Petrik, I.D.; Liu, J.; Lu, Y. Metalloenzyme design and engineering through strategic modifications of native protein scaffolds. Curr. Opin. Chem. Biol. 2014, 19, 67-75. [CrossRef] [PubMed]

11. Yu, Y.; Hu, C.; Xia, L.; Wang, J. Artificial metalloenzyme design with unnatural amino acids and non-native cofactors. ACS Catal. 2018, 8, 1851-1863. [CrossRef]

12. Jeschek, M.; Reuter, R.; Heinisch, T.; Trindler, C.; Klehr, J.; Panke, S.; Ward, T.R. Directed evolution of artificial metalloenzymes for in vivo metathesis. Nature 2016, 537, 661-665. [CrossRef] [PubMed] 
13. Chino, M.; Leone, L.; Zambrano, G.; Pirro, F.; D’Alonzo, D.; Firpo, V.; Aref, D.; Lista, L.; Maglio, O.; Nastri, F.; et al. Oxidation catalysis by iron and manganese porphyrins within enzyme-like cages. Biopolymers 2018. [CrossRef] [PubMed]

14. Yu, Y.; Cui, C.; Liu, X.; Petrik, I.D.; Wang, J.; Lu, Y. A designed metalloenzyme achieving the catalytic rate of a native enzyme. J. Am. Chem. Soc. 2015, 137, 11570-11573. [CrossRef] [PubMed]

15. Oohora, K.; Meichin, H.; Kihira, Y.; Sugimoto, H.; Shiro, Y.; Hayashi, T. Manganese(V) porphycene complex responsible for inert c-h bond hydroxylation in a myoglobin matrix. J. Am. Chem. Soc. 2017, 139, 18460-18463. [CrossRef] [PubMed]

16. Oohora, K.; Meichin, H.; Zhao, L.; Wolf, M.W.; Nakayama, A.; Hasegawa, J.; Lehnert, N.; Hayashi, T. Catalytic cyclopropanation by myoglobin reconstituted with iron porphycene: Acceleration of catalysis due to rapid formation of the carbene species. J. Am. Chem. Soc. 2017, 139, 17265-17268. [CrossRef] [PubMed]

17. Dydio, P.; Key, H.M.; Nazarenko, A.; Rha, J.Y.; Seyedkazemi, V.; Clark, D.S.; Hartwig, J.F. An artificial metalloenzyme with the kinetics of native enzymes. Science 2016, 354, 102-106. [CrossRef] [PubMed]

18. Key, H.M.; Dydio, P.; Clark, D.S.; Hartwig, J.F. Abiological catalysis by artificial haem proteins containing noble metals in place of iron. Nature 2016, 534, 534-537. [CrossRef] [PubMed]

19. Arnold, F.H. Directed evolution: Bringing new chemistry to life. Angew. Chem. Int. Ed. 2017, 56, 2-8. [CrossRef] [PubMed]

20. Hammer, S.C.; Kubik, G.; Watkins, E.; Huang, S.; Minges, H.; Arnold, F.H. Anti-Markovnikov alkene oxidation by metal-oxo-mediated enzyme catalysis. Science 2017, 358, 215-218. [CrossRef] [PubMed]

21. Kan, S.B.J.; Lewis, R.D.; Chen, K.; Arnold, F.H. Directed evolution of cytochrome c for carbon-silicon bond formation: Bringing silicon to life. Science 2016, 354, 1048-1051. [CrossRef] [PubMed]

22. Kan, S.B.J.; Huang, X.; Gumulya, Y.; Chen, K.; Arnold, F.H. Genetically programmed chiral organoborane synthesis. Nature 2017, 552, 132-136. [CrossRef] [PubMed]

23. Chen, K.; Huang, X.; Kan, S.B.J.; Zhang, R.K.; Arnold, F.H. Enzymatic construction of highly strained carbocycles. Science 2018, 360, 71-75. [CrossRef] [PubMed]

24. Caserta, G.; Chino, M.; Firpo, V.; Zambrano, G.; Leone, L.; D’Alonzo, D.; Nastri, F.; Maglio, O.; Pavone, V.; Lombardi, A. Enhancement of peroxidase activity in the artificial Mimochrome VI catalysts through rational design. ChemBioChem. 2018. [CrossRef] [PubMed]

25. Watkins, D.W.; Jenkins, J.M.X.; Grayson, K.J.; Wood, N.; Steventon, J.W.; Vay, K.K.L.; Goodwin, M.I.; Mullen, A.S.; Bailey, H.J.; Crump, M.P.; et al. Construction and in vivo assembly of a catalytically proficient and hyperthermostable de novo enzyme. Nat. Commun. 2017, 8, 358. [CrossRef] [PubMed]

26. Bilal, M.; Iqbalb, H.M.N.; Guoa, S.; Hua, H.; Wanga, W.; Zhang, X. State-of-the-art protein engineering approaches using biological macromolecules: A review from immobilization to implementation view point. Int. J. Biol. Macromol. 2018, 108, 893-901. [CrossRef] [PubMed]

27. Sheldon, R.A.; van Pelt, S. Enzyme immobilisation in biocatalysis: Why, what and how. Chem. Soc. Rev. 2013, 42, 6223-6235. [CrossRef] [PubMed]

28. Ansari, S.A.; Husain, Q. Potential applications of enzymes immobilized on/in nano materials: A review. Biotechnol. Adv. 2012, 30, 512-523. [CrossRef] [PubMed]

29. Algar, W.R.; Prasuhn, D.E.; Stewart, M.H.; Jennings, T.L.; Blanco-Canosa, J.B.; Dawson, P.E.; Medintz, I.L. The Controlled Display of Biomolecules on Nanoparticles: A Challenge Suited to Bioorthogonal Chemistry. Bioconjug. Chem. 2011, 22, 825-858. [CrossRef] [PubMed]

30. Katz, E.; Willner, I. Integrated nanoparticle-biomolecule hybrid systems: Synthesis, properties, and applications. Angew. Chem. Int. Ed. Engl. 2004, 43, 6042-6108. [CrossRef] [PubMed]

31. Zdarta, J.; Meyer, A.S.; Jesionowski, T.; Pinelo, M. A General overview of support materials for enzyme immobilization: Characteristics, properties, practical utility. Catalysts 2018, 8, 92. [CrossRef]

32. Chen, M.; Zeng, G.; Xu, P.; Lai, C.; Tang, L. How do enzymes 'meet' nanoparticles and nanomaterials? Trends Biochem. Sci. 2017, 42, 914-930. [CrossRef] [PubMed]

33. Cipolatti, E.P.; Silva, M.J.A.; Klein, M.; Feddern, V.; Feltes, M.C.; Oliveira, J.V.; Ninow, J.L.; de Oliveira, D. Current status and trends in enzymatic nanoimmobilization. J. Mol. Cat. B 2014, 99, 56-67. [CrossRef]

34. Auriemma, F.; de Rosa, C.; Malafronte, A.; Di Girolamo, R.; Santillo, C.; Gerelli, Y.; Fragneto, G.; Barker, R.; Pavone, V.; Maglio, O.; et al. Nano-in-nano approach for enzyme immobilization based on block copolymers. ACS Appl. Mater. Interfaces 2017, 9, 29318-29327. [CrossRef] [PubMed] 
35. Daniel, M.C.; Astruc, D. Gold nanoparticles: Assembly, supramolecular chemistry, quantum-size-related properties, and applications toward biology, catalysis, and nanotechnology. Chem. Rev. 2004, 104, $293-346$. [CrossRef] [PubMed]

36. Jia, H.; Zhu, G.; Wang, P. Catalytic behaviors of enzymes attached to nanoparticles: The effect of particle mobility. Biotechnol. Bioeng. 2003, 84, 406-414. [CrossRef] [PubMed]

37. Noll, T.; Noll, G. Strategies for "wiring" redox-active proteins to electrodes and applications in biosensors, biofuel cells, and nanotechnology. Chem. Soc. Rev. 2011, 40, 3564-3576. [CrossRef] [PubMed]

38. Schneider, E.; Clark, D.S. Cytochrome P450 (CYP) enzymes and the development of CYP biosensors. Biosens. Bioelectron. 2013, 39, 1-13. [CrossRef] [PubMed]

39. Sadeghi, S.J.; Fantuzzi, G.; Gilardi, G. Breakthrough in P450 bioelectrochemistry and future perspectives. Biochim. Biophys. Acta 2011, 1814, 237-248. [CrossRef] [PubMed]

40. Netto, C.G.C.M.; Toma, H.E.; Andrade, L.H. Superparamagnetic nanoparticles as versatile carriers and supporting materials for enzymes. J. Mol. Cat. B 2013, 85-86, 71-92. [CrossRef]

41. Lu, D.; Pang, G. A novel tetrahydrocannabinol electrochemical nano immunosensor based on horseradish peroxidase and double-layer gold nanoparticles. Molecules 2016, 21, 1377. [CrossRef] [PubMed]

42. Tang, D.; Tang, J.; Su, B.; Li, Q.; Chen, G. Electrochemical detection of hepatitis C virus with signal amplification using Bam $\mathrm{HI}$ endonuclease and horseradish peroxidase-encapsulated nanogold hollow spheres. Chem. Commun. 2011, 47, 9477-9479. [CrossRef] [PubMed]

43. Nastri, F.; Lombardi, A.; Morelli, G.; Maglio, O.; D’Auria, G.; Pedone, C.; Pavone, V. Hemoprotein Models Based on a Covalent Helix-Heme-Helix Sandwich: 1. Design, Synthesis, and Characterization. Chem. Eur. J. 1997, 3, 340-349. [CrossRef]

44. D’Auria, G.; Maglio, O.; Nastri, F.; Lombardi, A.; Mazzeo, M.; Morelli, G.; Paolillo, L.; Pedone, C.; Pavone, V. Hemoprotein Models Based on a Covalent Helix-Heme-Helix Sandwich: 2. Structural Characterization of Co ${ }^{\mathrm{III} M i m o c h r o m e ~ I ~} \delta$ and $\delta$ Isomers. Chem. Eur. J. 1997, 3, 350-362. [CrossRef]

45. Nastri, F.; Lombardi, A.; Morelli, G.; Pedone, C.; Pavone, V.; Chottard, G.; Battioni, P.; Mansuy, D. Hemoprotein models based on a covalent helix-heme-helix sandwich. 3. Coordination properties, reactivity and catalytic application of Fe(III)- and Fe(II)-mimochrome I. J. Biol. Inorg. Chem. 1998, 3, 671-681. [CrossRef]

46. Lombardi, A.; Nastri, F.; Sanseverino, M.; Maglio, O.; Pedone, C.; Pavone, V. Miniaturized hemoproteins: Design, synthesis and characterization of mimochrome II. Inorg. Chim. Acta 1998, 301, 275-276. [CrossRef]

47. Lombardi, A.; Nastri, F.; Pavone, V. Peptide-based heme-protein models. Chem. Rev. 2001, 101, 3165-3189. [CrossRef] [PubMed]

48. Lombardi, A.; Nastri, F.; Marasco, D.; Maglio, O.; De Sanctis, G.; Sinibaldi, F.; Santucci, R.; Coletta, M.; Pavone, V. Design of a new mimochrome with unique topology. Chem. Eur. J. 2003, 9, 5643-5654. [CrossRef] [PubMed]

49. Di Costanzo, L.; Geremia, S.; Randaccio, L.; Nastri, F.; Maglio, O.; Lombardi, A.; Pavone, V. Miniaturized heme proteins: Crystal structure of Co(III)-mimochrome IV. J. Biol. Inorg. Chem. 2004, 9, 1017-1027. [CrossRef] [PubMed]

50. Nastri, F.; Lista, L.; Ringhieri, P.; Vitale, R.; Faiella, M.; Andreozzi, C.; Travascio, P.; Maglio, O.; Lombardi, A.; Pavone, V. A Heme-peptide metalloenzyme mimetic with natural peroxidase-like activity. Chem. Eur. J. 2011, 17, 4444-4453. [CrossRef] [PubMed]

51. Vicari, C.; Saraiva, I.H.; Maglio, O.; Nastri, F.; Pavone, V.; Louro, R.O.; Lombardi, A. Artificial heme-proteins: Determination of axial ligand orientations through paramagnetic NMR shifts. Chem. Commun. 2014, 50, 3852-3855. [CrossRef] [PubMed]

52. Ranieri, A.; Monari, S.; Sola, M.; Borsari, M.; Battistuzzi, G.; Ringhieri, P.; Nastri, F.; Pavone, V.; Lombardi, A. Redox and electrocatalytic properties of mimochrome VI, a synthetic heme peptide adsorbed on gold. Langmuir 2010, 26, 17831-17835. [CrossRef] [PubMed]

53. Vitale, R.; Lista, L.; Lau-Truong, S.; Tucker, R.T.; Brett, M.J.; Limoges, B.; Pavone, V.; Lombardi, A.; Balland, V. Spectroelectrochemistry of FeIII- and CoIII-mimochrome VI artificial enzymes immobilized on mesoporous ITO electrodes. Chem. Commun. 2014, 50, 1894-1896. [CrossRef] [PubMed]

54. Vitale, R.; Lista, L.; Cerrone, C.; Caserta, G.; Chino, M.; Maglio, O.; Nastri, F.; Pavone, V.; Lombardi, A. An artificial heme-enzyme with enhanced catalytic activity: Evolution, functional screening and structural characterization. Org. Biomol. Chem. 2015, 13, 4859-4868. [CrossRef] [PubMed] 
55. Ding, S.; Cargill, A.A.; Medintz, I.L.; Claussen, J.C. Increasing the activity of immobilized enzymes with nanoparticle conjugation. Curr. Opin. Biotech. 2015, 34, 242-250. [CrossRef] [PubMed]

56. Walper, S.A.; Turner, K.B.; Medintz, I.L. Enzymatic bioconjugation of nanoparticles: Developing specificity and control. Curr. Opin. Biotech. 2015, 34, 232-241. [CrossRef] [PubMed]

57. Ahmad, R.; Sardar, M. Enzyme Immobilization: An Overview on Nanoparticles as Immobilization Matrix. Anal. Biochem. 2015, 4. [CrossRef]

58. Ulman, A. Formation and structure of self-assembled monolayers. Chem. Rev. 1996, 96, 1533-1554. [CrossRef] [PubMed]

59. Wink, T.; van Zuilen, S.J.; Bult, A.; van Bennekom, W.P. Self-assembled monolayers for biosensors. Analyst 1997, 122, 43R-50R. [CrossRef]

60. Mahl, D.; Greulich, C.; Meyer-Zaika, W.; Koller, M.; Epple, M. Gold nanoparticles: Dispersibility in biological media and cell-biological effect. J. Mater. Chem. 2010, 20, 6176-6181. [CrossRef]

61. Pérez-Rentero, S.; Grijalvo, S.; Peñuelas, G.; Fàbrega, C.; Eritja, R. Thioctic acid derivatives as building blocks to incorporate DNA oligonucleotides onto gold nanoparticles. Molecules 2014, 19, 10495-10523. [CrossRef] [PubMed]

62. Koufaki, M.; Detsi, A.; Kiziridi, C. Multifunctional lipoic acid conjugates. Curr. Med. Chem. 2009, 16, 4728-4742. [CrossRef] [PubMed]

63. Maglio, O.; Costanzo, S.; Cercola, R.; Zambrano, G.; Mauro, M.; Battaglia, R.; Ferrini, G.; Nastri, F.; Pavone, V.; Lombardi, A. QCM immunosensor for stem cell selection and extraction. Sensors 2017, 17, 2747. [CrossRef] [PubMed]

64. Ahirwal, G.K.; Mitra, C.K. Direct electrochemistry of horseradish peroxidase-gold nanoparticles conjugate. Sensors 2009, 9, 881-894. [CrossRef] [PubMed]

65. Onoda, A.; Ueya, Y.; Sakamoto, T.; Uematsua, T.; Hayashi, T. Supramolecular hemoprotein-gold nanoparticle conjugates. Chem. Commun. 2010, 46, 9107-9109. [CrossRef] [PubMed]

66. Dougan, J.A.; Karlsson, C.; Smith, W.E.; Graham, D. Enhanced oligonucleotide—nanoparticle conjugate stability using thioctic acid modified oligonucleotides. Nucleic Acids Res. 2007, 35, 3668-3675. [CrossRef] [PubMed]

67. Sharp, M.; Petersson, M.; Edstrom, K.J. Preliminary determinations of electron transfer kinetics involving ferrocene covalently attached to a platinum surface. J. Electroanal. Chem. 1979, 95, 123-130. [CrossRef]

68. Bard, A.J.; Faulkner, L.R. Electrochemical Methods, Fundamentals and Applications, 2nd ed.; John Wiley \& Sons Inc.: New York, NY, USA, 2001; ISBN 0471043729.

69. Zhao, P.; Li, N.; Astruc, D. State of the art in gold nanoparticle synthesis. Coord. Chem. Rev. 2013, 257, 638-665. [CrossRef]

70. Turkevich, J.; Stevenson, P.C.; Hillier, J. A study of the nucleation and growth processes in the synthesis of colloidal gold. Discuss. Faraday Soc. 1951, 11, 55-75. [CrossRef]

71. Templeton, A.C.; Pietron, J.J.; Murray, R.W.; Mulvaney, P. Solvent refractive index and core charge influences on the surface plasmon absorbance of alkanethiolate monolayer-protected gold clusters. J. Phys. Chem. B 2000, 104, 564-570. [CrossRef]

72. De Carlo, S.; Harris, J.R. Negative staining and cryo-negative staining of macromolecules and viruses for TEM. Micron 2011, 42, 117-131. [CrossRef] [PubMed]

73. Michen, B.; Geers, C.; Vanhecke, D.; Endes, C.; Rothen-Rutishauser, B.; Balog, S.; Petri-Fink, A. Avoiding drying-artifacts in transmission electron microscopy: Characterizing the size and colloidal state of nanoparticles. Sci. Rep. 2015, 5, 9793. [CrossRef] [PubMed]

74. Mattoussi, H.; Mauro, J.M.; Goldman, E.R.; Anderson, G.P.; Sundar, V.C.; Mikulec, F.V.; Bawendi, M.G. Self-assembly of CdSe-ZnS quantum dot bioconjugates using an engineered recombinant protein. J. Am. Chem. Soc. 2000, 122, 12142-12150. [CrossRef]

75. Cebula, J.; Ottewill, R.H.; Ralston, J.; Pusey, P.N. Investigations of microemulsions by light scattering and neutron scattering. J. Chem. Soc. Faraday Trans. 1 1981, 77, 2585-2612. [CrossRef]

76. Lobanov, M.Y.; Bogatyreva, N.S.; Galzitskaya, O.V. Radius of Gyration as an Indicator of Protein Structure Compactness. Mol. Biol. 2008, 42, 623-628. [CrossRef]

77. Dewald, I.; Isakin, O.; Schubert, J.; Kraus, T.; Chanana, M. Protein identity and environmental parameters determine the final physicochemical properties of protein-coated metal nanoparticles. J. Phys. Chem. C 2015, 119, 25482-25492. [CrossRef] 
78. Rodrigues, R.C.; Ortiz, C.; Berenguer-Murcia, A.; Torres, R.; Fernández-Lafuente, R. Modifying enzyme activity and selectivity by immobilization. Chem. Soc. Rev. 2013, 42, 6290-6307. [CrossRef] [PubMed]

79. Santos, J.C.S.D.; Barbosa, O.; Ortiz, C.; Berenguer-Murcia, A.; Rodrigues, R.C.; Fernandez-Lafuente, R. Importance of the support properties for immobilization or purification of enzymes. ChemCatChem. 2015, 7, 2413-2432. [CrossRef]

80. Männel, M.J.; Kreuzer, L.P.; Goldhahn, C.; Schubert, J.; Hart, M.J.; Chanana, M. Catalytically active protein coatings: Toward enzymatic cascade reactions at the intercolloidal level. ACS Catal. 2017, 7, 1664-1672. [CrossRef]

81. Ni, Y.; Li, Y.; Huang, Z.; He, K.; Zhuang, J.; Yang, W. Improved activity of immobilized horseradish peroxidase on gold nanoparticles in the presence of bovine serum albumin. J. Nanopart. Res. 2013, 15, 2038. [CrossRef]

82. Tadepalli, S.; Wang, Z.; Slocik, J.; Naik, R.R.; Singamanen, S. Effect of size and curvature on the enzyme activity of bionanoconjugates. Nanoscale 2017, 9, 15666-15672. [CrossRef] [PubMed]

83. Lata, J.P.; Gao, L.; Mukai, C.; Cohen, R.; Nelson, J.L.; Anguish, L.; Coonrod, S.; Travis, A.J. Effects of nanoparticle size on multilayer formation and kinetics of tethered enzymes. Bioconjug. Chem. 2015, 26, 1931-1938. [CrossRef] [PubMed]

84. Jamison, J.A.; Bryant, E.L.; Kadali, S.B.; Wong, M.S.; Colvin, V.L.; Matthews, K.S.; Calabretta, M.K. Altering protein surface charge with chemical modification modulates protein-gold nanoparticle aggregation. J. Nanopart. Res. 2011, 13, 625-636. [CrossRef]

85. Frens, G. Controlled nucleation for the regulation of the particle size in monodisperse gold suspensions. Nat. Phys. Sci. 1973, 241, 20-22. [CrossRef]

86. Haiss, W.; Thanh, N.T.K.; Aveyard, J.; Fernig, D.G. Determination of size and concentration of gold nanoparticles from UV-vis spectra. Anal. Chem. 2007, 79, 4215-4221. [CrossRef] [PubMed]

87. Carvalhal, R.F.; Freire, R.S.; Kubota, L.T. Polycrystalline gold electrodes: A comparative study of pretreatment procedures used for cleaning and thiol self-assembly monolayer formation. Electroanalysis 2005, 17, 1251-1259. [CrossRef]

88. Ranganathan, S.; Kuo, T.-C.; McCreery, R.L. Facile preparation of active glassy carbon electrodes with activated carbon and organic solvents. Anal. Chem. 1999, 71, 3574-3580. [CrossRef]

89. Childs, R.E.; Bardsley, W.G. The steady-state kinetics of peroxidase with 2,2' -azino-di-(3-ethyl-benzthiazoline6-sulphonic acid) as chromogen. Biochem. J. 1975, 145, 93-103. [CrossRef] [PubMed]

90. Cleland, W.W. The kinetics of enzyme-catalyzed reactions with two or more substrates or products. I. Nomenclature and rate equations. Biochim. Biophys. Acta 1963, 67, 104-137. [CrossRef] 